\title{
Speciation, risks and isotope-based source apportionment of trace elements in soils of the northeastern Qinghai-Tibet Plateau
}

\author{
Leiming $\mathrm{Li}^{1,2,3}$, Jun $\mathrm{Wu}^{1,2,3^{*}}$, Jian $\mathrm{Lu}^{3,4}$ \& Juan $\mathrm{Xu}^{5}$ \\ ${ }^{1}$ Key Laboratory of Comprehensive and Highly Efficient Utilization of Salt Lake Resources, Qinghai Institute of Salt Lakes, \\ Chinese Academy of Sciences, Xining, Qinghai 810008, China \\ ${ }^{2}$ Qinghai Provincial Key Laboratory of Geology and Environment of Salt Lakes, Qinghai Institute of Salt Lakes, Chinese \\ Academy of Sciences, Xining, Qinghai 810008, China \\ ${ }^{3}$ College of Earth and Planetary Sciences, University of Chinese Academy of Sciences, Beijing 100049, China \\ ${ }^{4}$ CAS Key Laboratory of Coastal Environmental Processes and Ecological Remediation, Yantai Institute of Coastal Zone \\ Research (YIC), Chinese Academy of Sciences (CAS), Shandong Key Laboratory of Coastal Environmental Processes, \\ YICCAS, Yantai Shandong 264003, China \\ ${ }^{5}$ State Key Laboratory of Marine Geology, Tongji University, Shanghai 200092, China \\ *Correspondence: wujunlisa@163.com
}

\begin{abstract}
Trace elements in soils might cause contamination and ecological risks to the environment with increasing anthropogenic disturbance. This study investigated the distribution, speciation, risks and possible sources of 28 target trace elements in soils of the northeastern Qinghai-Tibet Plateau. The average concentrations of trace elements in soils of the study area ranged from $0.25(\mathrm{Hg})$ to $697.38 \mathrm{mg} \mathrm{kg}^{-1}(\mathrm{Cr})$. The residual fraction was the dominant host of $\mathrm{V}, \mathrm{Cr}, \mathrm{Cu}, \mathrm{Sn}, \mathrm{Sb} \mathrm{Hg}$ and REEs, while $\mathrm{Co}, \mathrm{Ni}, \mathrm{Zn}, \mathrm{Mo}, \mathrm{Cd}$ and $\mathrm{Pb}$ had large proportions in the non-residual fractions. Risk assessment code analysis showed that $\mathrm{Cd}$ should be recognized as a priority pollutant in the study area. Correlation analysis indicated that $\mathrm{Pb}, \mathrm{Cu}, \mathrm{Zn}, \mathrm{Cd}$ and $\mathrm{Sn}$ might originate from the same or similar source. The ${ }^{206} \mathrm{~Pb} /{ }^{207} \mathrm{~Pb}$ and ${ }^{208} \mathrm{~Pb} /{ }^{206} \mathrm{~Pb}$ ratios of the soils were in the range of $1.166-1.224$ and 2.031-2.122, respectively. The anthropogenic $\mathrm{Pb}$ contribution proportion was in the range of $0-53.92 \%$ for the study area. The anthropogenic $\mathrm{Pb}$ contribution was higher in the areas with more intensive anthropogenic activities. Heavy metals and excessive anthropogenic disturbance should be effectively controlled in the northeastern Qinghai-Tibet Plateau to maintain the ecological sustainability and human health of this fragile area.
\end{abstract}

Keywords: trace element; speciation; risk assessment; $\mathrm{Pb}$ isotopic fingerprint; the Qinghai-Tibet Plateau

Received 5 June 2019; revised 3 August 2019; accepted 6 August 2019

Soil pollution induced by trace elements has attracted wide attention in recent decades. Trace elements originating from natural or anthropogenic sources ubiquitously exist in various environments including soils, sediments and water (Seshan et al. 2010; Lee et al. 2011; Li \& Ji 2017). Weathering of minerals is one important natural source for trace elements in soils. Anthropogenic sources of trace elements in soils mainly include industrial/mining wastes and non-point pollution sources ( $\mathrm{Wu}$ et al. 2016, 2018b). Trace elements do not decompose through natural processes, whereas they might be easily transformed to organic complexes with higher toxicity and accumulate in organisms. Speciation of trace elements has significant impacts on the mobility, bioavailability and potential risks of these elements (Dessai \& Nayak 2009; Fernandes et al. 2014). The mobility of soil trace elements with different chemical forms follows the order of exchangeable $>$ carbonate $>\mathrm{Fe}-\mathrm{Mn}$ oxide bound $>$ organic bound $>$ residual (Fernandes \& Nayak 2015). Therefore, chemical speciation will provide more comprehensive information to evaluate the potential impacts, mobility and bioavailability of trace elements (Ke et al. 2017; Liang et al. 2017; Meng et al. 2018). Moreover, application of a risk assessment code (RAC) using chemical speciation of trace elements will also provide more accurate information on potential risks of these elements (Zhu et al. 2012).

Source identification is critical for pollution control and prevention. The traditional approaches of source identification rely on statistically analysing numerous data (Han et al. 2018). However, these methods exhibit some shortcomings such as the need to employ indirect inference and the requirement of large amounts of data. Stable isotopes, which can be considered as the 'signature' of elements, have shown advantages for source apportionment of trace elements in soil (Zhang et al. 2017; G. Li et al. 2018). $\mathrm{Pb}$ isotope ratios have been increasingly applied to yield information on geochemical origins, to determine the principal sources of anthropogenic $\mathrm{Pb}$, to identify the transport pathways of $\mathrm{Pb}$ and to calculate the contribution percentage of anthropogenic sources (Yu et al. 2013; Kong et al. 2018).

The northeastern Qinghai-Tibet Plateau is more populated and industrialized than the other parts of this plateau (Wu et al. 2016, 2018a; L. Li et al. 2018). Therefore, the objective of this study is to identify the speciation, risks and possible sources of trace elements in soils of the northeastern Qinghai-Tibet Plateau. The final goal is to provide useful information on soil quality maintenance in the high-elevation areas.

\section{Materials and methods}

\section{Study area and sampling strategy}

The study area is located in the northeastern Qinghai-Tibet Plateau. A total of 17 topsoil $(0-20 \mathrm{~cm})$ samples were collected in June 2017 to represent the typical soil of the agricultural and pastoral zone (APA-1, APA-2, APA-3 and APA-4), industrial zone (IA-1, IA-2, IA-3 and IA-4), mining zone (MA-1, MA-2, MA-3 and MA-4), and salt-lake zone (SLA-1, SLA-2, SLA-3, SLA-4 and SLA-5) of the study area (Fig. 1). The topsoil samples were stored in polyethylene bags and taken back to the laboratory as soon as possible. 


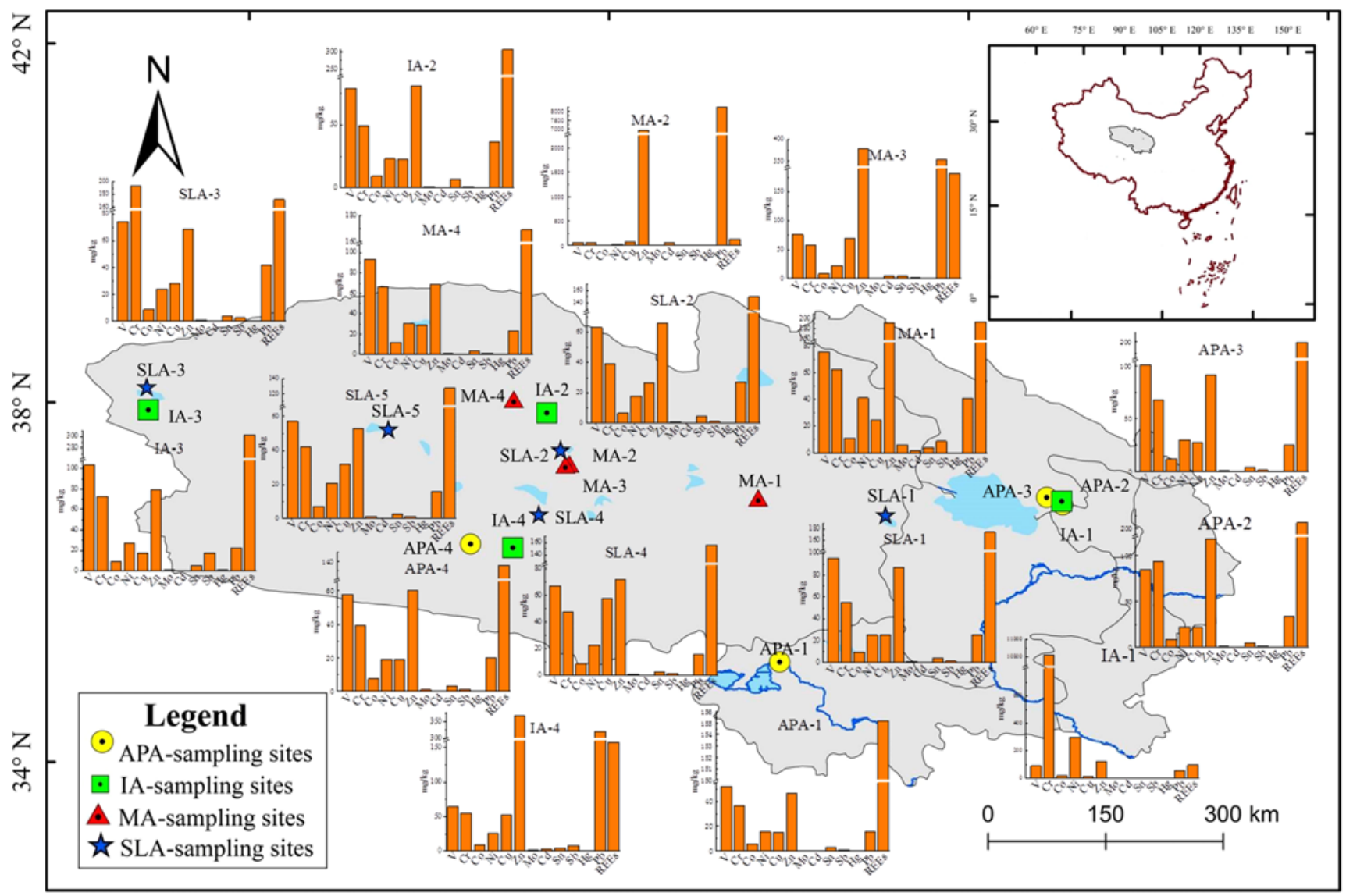

Fig. 1. Study area, sampling sites and distribution of trace elements in soils. APA, IA, MA and SLA refer to the agricultural and pastoral area, industrial area, mining area, and salt-lake area, respectively.

\section{Sequential extraction procedures}

The sequential extraction procedure proposed by Tessier et al. (1979) was proved to be effective for analysing speciation of trace elements in soils or sediments (Fernandes \& Nayak 2015). Therefore, this method was selected to determine the fraction of trace elements in soil samples from the study area. Following the sequential extraction procedure (Tessier et al. 1979), five fractions were analysed for trace elements including the exchangeable fraction (F1), the carbonates fraction (F2), the Fe-Mn oxide fraction (F3), the organic matter fraction (F4) and the residual fraction (F5).

The supernatants from each sequential extraction step were filtered through a $0.45 \mu \mathrm{m}$ cellulose acetate syringe filter, and then stored in the fridge at $-4^{\circ} \mathrm{C}$ until analysis. The concentrations of trace element in each step were determined using an Agilent7900 inductively coupled plasma mass spectrometer (ICP-MS: Agilent Inc., USA). The soil digestion procedure and the determination of the total content of trace elements in soils are described in previous reports (Wu et al. 2018a, b). The trace elements included 12 typical heavy metals $(\mathrm{Pb}, \mathrm{Cd}, \mathrm{Cr}, \mathrm{Ni}, \mathrm{Zn}, \mathrm{Mo}, \mathrm{Cu}, \mathrm{Sn}, \mathrm{Hg}, \mathrm{Co}, \mathrm{Sb}$ and $\mathrm{V}$ ) and 16 rare earth elements (REEs: $\mathrm{La}, \mathrm{Ce}, \mathrm{Pr}, \mathrm{Nd}, \mathrm{Sm}, \mathrm{Eu}, \mathrm{Gd}, \mathrm{Tb}$, Dy, Ho, Er, Tm, Yb, Lu, Sc and Y). The determination of soil physicochemical properties are described in previous studies $(\mathrm{L} . \mathrm{Li}$ et al. 2018; Wu et al. 2018a, b)

\section{Risk assessment of trace elements}

The risk assessment code (RAC) was used to determine the potential ecological risks of trace elements in soils of the study area. The RAC was calculated as the percentage sum of exchangeable and carbonate forms. Ecological risk was categorized into five levels including safe ( $\mathrm{RAC}<1 \%$ ), low (RAC in the range $1-10 \%$ ), medium (RAC in the range $11-30 \%$ ), high (RAC in the range $31-50 \%$ ) and dangerous/very high risk (RAC $>50 \%$ ) according to a previous report (Chen et al. 2018).

\section{Source identification by Pb isotopes}

The combination of measurable and unique characteristics of $\mathrm{Pb}$ isotopes that are preserved during transport, processing and degradation of the original materials have provided a useful tool for source apportionment of $\mathrm{Pb}$ pollution. Lead isotopic determination is based on the principle that $\mathrm{Pb}$ has four natural isotopes. Different types of anthropogenic sources and ore deposits of $\mathrm{Pb}$ have different isotope ratios and signatures. Lead isotopic fractionation does not occur during environmental or industrial processes (Zhang et al. 2007; Cheng \& Hu 2010; G. Li et al. 2018). Therefore, this study used a binary model to make an arbitrary calculation for anthropogenic source:

$$
\begin{gathered}
\left({ }^{206} \mathrm{~Pb} /{ }^{207} \mathrm{~Pb}\right)_{\text {nat }} f_{1}+\left({ }^{206} \mathrm{~Pb} /{ }^{207} \mathrm{~Pb}\right)_{\text {ant }} f_{2}=\left({ }^{206} \mathrm{~Pb} /{ }^{207} \mathrm{~Pb}\right)_{\text {sample }} \\
f_{1}+f_{2}=100 \%
\end{gathered}
$$

where 'ant' and 'nat' refer to the anthropogenic and natural fractions, respectively; $f_{1}$ and $f_{2}$ are the fractional contributions of the natural and anthropogenic sources, respectively. The isotopic ratio of ${ }^{206} \mathrm{~Pb} /{ }^{207} \mathrm{~Pb}$ in unpolluted soils was about 1.20 . The ${ }^{206} \mathrm{~Pb} /{ }^{207} \mathrm{~Pb}$ background value for soils of the Qinghai-Tibet Plateau was set as 1.2004 by averaging the results of soils (J.-Z. Feng et al. 2010; X. Feng et al. 2010) and local dust (Cong et al. 2011). Lead in soil was considered to originate from natural sources when the ${ }^{206} \mathrm{~Pb} /{ }^{207} \mathrm{~Pb}$ value was higher than 1.2004 . The ${ }^{206} \mathrm{~Pb} /{ }^{207} \mathrm{~Pb}$ of anthropogenic sources for western China was simplified and roughly estimated as 1.1365 , which was calculated 


\section{Speciation and source of trace elements in soils}

from an aerosol from Russia (Bollhöfer \& Rosman 2001; Mukai et al. 2001; Yu et al. 2013). Lead in soil was considered to originate from the anthropogenic sources if ${ }^{206} \mathrm{~Pb} /{ }^{207} \mathrm{~Pb}$ value was less than 1.1365 .

Analyses of $\mathrm{Pb}$ isotopic compositions were conducted at Beijing Research Institute of Uranium Geology. Lead isotopic ratios were measured using a mass spectrometer (IsoProbe-T) based on the 'Standard for Determination of Trace Lead Isotopic Composition in Rocks and Minerals (DZ/T 0184.12-997). A certified reference material (NBS981, USA) was used for quality control/assurance with the certified ${ }^{208} \mathrm{~Pb} /{ }^{206} \mathrm{~Pb},{ }^{207} \mathrm{~Pb} /{ }^{206} \mathrm{~Pb}$ and ${ }^{204} \mathrm{~Pb} /{ }^{206} \mathrm{~Pb}$ values of $2.1684 \pm 0.0008,0.91464 \pm 0.00033$ and $0.059042 \pm 0.000037$, respectively. The $\mathrm{Pb}$ isotopic ratios of 17 soil samples in this study were measured in duplicate with relative standard deviations of less than $0.5 \%$.

Pearson's correlation matrix (PCM) was adopted to discuss the relationship between trace elements. PCM was performed using SPSS 22.0 (IBM, New York, USA).

\section{Results and discussion}

\section{Soil characteristics}

The major type of 17 soil samples in the study area was sandy clay loam based on soil texture analysis. The average $\mathrm{pH}$ of soils in the study area was 8.50 with a range of 7.96-9.28, indicating that soils in the study area are alkaline. The cation exchange capacity of the soils showed the significant spatial variation to range from 1.43 to $42.02 \mathrm{cmol} \mathrm{kg}^{-1}$ (centimoles of positive charge per kg of soil) with an average value of $9.53 \mathrm{cmol} \mathrm{kg}^{-1}$. The contents of soil total organic carbon also significantly varied with a range of $0.13-3.85 \mathrm{~g} \mathrm{~kg}^{-1}$.

\section{Distribution of trace elements in soils of the study area}

The distribution of heavy metals in soils of the study area showed significant spatial variation (Fig. 1). The average concentration of target heavy metals in soils of the northeastern Qinghai-Tibet Plateau ranged from $0.25(\mathrm{Hg})$ to $697 \mathrm{mg} \mathrm{kg}^{-1}(\mathrm{Cr})$ by following the order $\mathrm{Cr}>\mathrm{Pb}>\mathrm{Zn}>\mathrm{V}>\mathrm{Ni}>\mathrm{Cu}>\mathrm{Co}>\mathrm{Sn}>\mathrm{Sb}>\mathrm{Cd}>\mathrm{Mo}>\mathrm{Hg}$. The average concentration of $\mathrm{Cr}$ was about 10 times its background value, while the average concentration of $\mathrm{Pb} / \mathrm{Zn}$ was about 26/6 times its corresponding background value. Soil samples collected from site IA-1 near a chemical factory in the eastern study area possessed the highest concentration of $\mathrm{Cr}$ with $10818 \mathrm{mg} \mathrm{kg}^{-1}$, while soil samples collected from site MA-2 near a lead-zinc mine in the middle of the study area showed the highest concentration of $\mathrm{Pb}$ and $\mathrm{Zn}$ with values of 8258 and $6874 \mathrm{mg} \mathrm{kg}^{-1}$, respectively. The mean concentration of $\mathrm{Cd} / \mathrm{Hg}$ was about $27 / 13$ times its background value, while the average concentrations of $\mathrm{Sb}$ and $\mathrm{Sn}$ were about 3 and 2 times the corresponding background value, respectively. Site IA-3, located at an oilfield in the western study area, exhibited the maximal concentration of $\mathrm{Hg}\left(0.80 \mathrm{mg} \mathrm{kg}^{-1}\right)$ in soil, while site MA2 near a lead-zinc mine in the middle of the study area showed the highest concentration of $\mathrm{Cd}$ with $50 \mathrm{mg} \mathrm{kg}^{-1}$. The mean concentrations of $\mathrm{V} / \mathrm{Co} / \mathrm{N} / \mathrm{Cu} / \mathrm{Mo}$ were similar to their corresponding background values. The concentrations of heavy metals in the soils were similar to those in the soils of the Huangshui watershed and the Karuola Glacier in the Qinghai-Tibet Plateau (Dai et al. 2019; Zhang et al. 2019).

The content of total REEs in soil samples collected from the study area ranged from 97 to $307 \mathrm{mg} \mathrm{kg}^{-1}$, with an average value of $178 \mathrm{mg} \mathrm{kg}^{-1}$ (Fig. 1). Light REEs (LREEs) were the main components of the REEs in soils of the study area. LREEs including $\mathrm{Ce}, \mathrm{La}$ and $\mathrm{Nd}$ were the most abundant REEs in the soils, with average concentrations of 63,31 and $27 \mathrm{mg} \mathrm{kg}^{-1}$, respectively.
Three main heavy REEs (HREEs) including Y, Sc and Gd accounted for 11,6 and $3 \%$ of the total REEs, respectively. The average concentrations of individual REEs followed the order $\mathrm{Ce}>\mathrm{La}>\mathrm{Nd}>\mathrm{Y}>\mathrm{Sc}>\mathrm{Pr}>\mathrm{Sm}>\mathrm{Gd}>\mathrm{Dy}>\mathrm{Er}>\mathrm{Yb}>\mathrm{Eu}>\mathrm{Ho}>$ $\mathrm{Tb}>\mathrm{Lu}>\mathrm{Tm}$.

\section{Speciation of trace elements in soils of the study area}

The toxicity and bioavailability of trace elements can be ascertained based on the speciation of these elements. Anthropogenic trace elements exist in the exchangeable and adsorptive fractions, while the carbonate fraction is considered to weakly and easily equilibrate with the aqueous phase to become more bioavailable (Guo et al. 2011; Lin et al. 2014).

The chemical speciation of heavy metals in soils showed element-dependent features with significant spatial variation (Fig. 2). The residual fraction of each heavy metal in soils on average accounted for $29.9-99.7 \%$ of its total content. The residual fraction percentage of $\mathrm{V}, \mathrm{Cr}, \mathrm{Cu}, \mathrm{Sn}, \mathrm{Sb}$ and $\mathrm{Hg}$ in soils exceeded $50 \%$ on average, suggesting that it was not easy for these metals to become mobile in soils of the study area. Chromium existed in soils bound to the residual fraction $(93.9 \%)$, with the remaining four fraction contents ranging from 1.0 to $2.5 \%$. Copper existed in soils bound to the residual fraction $(71.6 \%)$ and the organic fraction (18.4\%). The chemical speciation of $\mathrm{Cu}$ in soils of the study area was significantly different from that in the tailing samples (Chen et al. 2018). Tin and Sb existed mostly bound to the residual fraction ( 99.7 and $93.0 \%$, respectively), with the rest of the four chemical forms occurring in the range of $0.0-0.2$ and $0.4-4.0 \%$. It is generally difficult for heavy metals existing in the organic matter fraction to be released under normal moderately reducing or weakly oxidizing environments (Lin et al. 2014). Therefore, $\mathrm{Cr}, \mathrm{Cu}, \mathrm{Sn}$ and $\mathrm{Sb}$ in soils of the study area might be relatively safe since they possessed weak release potential. Vanadium existed in soils as $83.7 \%$ bound in the residual fraction and $14.8 \%$ in the exchangeable fraction. The heavy metals in the exchangeable fraction are generally sensitive to environmental changes, and easy to migrate and transform (Lin et al. 2014). As a result, V might exhibit some bioavailability and toxicity. Mercury, on average, existed at $56.9 \%$ in soils in the residual fraction, $20.4 \%$ in the organic matter fraction, $9.8 \%$ in the exchangeable fraction, $8.7 \%$ in the $\mathrm{Fe}-\mathrm{Mn}$ oxide fraction and $4.2 \%$ in the carbonate fraction (4.2\%). The trace metals contained in the $\mathrm{Fe}-\mathrm{Mn}$ oxide or hydroxide fraction might be released if the oxidation-reduction potential decreases (Guo et al. 2011). Heavy metals bound to carbonate are easily released under acidic conditions (Guo et al. 2011). This indicated that $\mathrm{Hg}$ might represent some potential ecological risk.

The fractional profiles for $\mathrm{Co}, \mathrm{Ni}, \mathrm{Zn}, \mathrm{Mo}, \mathrm{Cd}$ and $\mathrm{Pb}$ were totally different from those for the other heavy metals because the nonresidual fractions were the main components for these metals. The dominant speciation of Co was the residual form with an average proportion of $39.3 \%$. However, the sum of the exchangeable, carbonate and $\mathrm{Fe}-\mathrm{Mn}$ oxide fractions reached $48.3 \%$ on average. The sum of the exchangeable, carbonate and $\mathrm{Fe}-\mathrm{Mn}$ oxide fractions of $\mathrm{Ni}$ was $47.3 \%$ on average, exceeding the proportion of the residual form (44.4\%). These results indicated that $\mathrm{Co}$ and $\mathrm{Ni}$ in the soils of the study area were generally sensitive to environmental changes and could readily migrate and transform. Zinc existed in soils bound to the residue (40.3\%), Fe-Mn oxide (26.8\%), organic matter $(22.3 \%)$ and carbonate $(9.6 \%)$ fractions. The average proportions of the exchangeable, carbonate and $\mathrm{Fe}-\mathrm{Mn}$ oxide fractions for Mo in soils reached 14.2, 5.3 and 24.4\%, respectively. Cadmium existed in soils mainly in the exchangeable $(6.3 \%)$, carbonate $(25.7 \%)$ and $\mathrm{Fe}-\mathrm{Mn}$ oxide $(16.7 \%)$ fractions. The results indicated that Mo and $\mathrm{Cd}$ had a potential ecological risk to the environment. Contrary to the other heavy metals, $\mathrm{Pb}$ existed in soils 

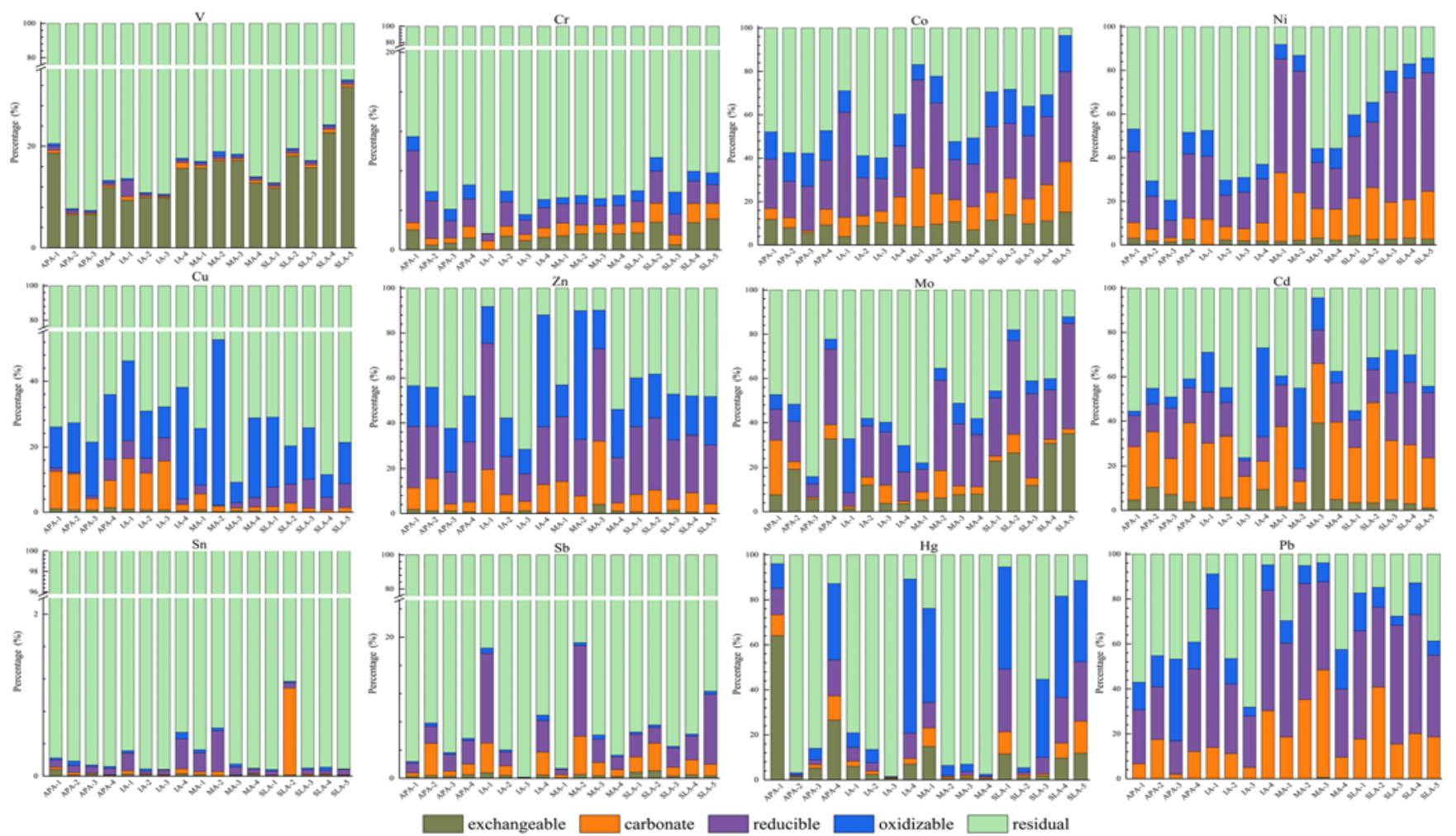

Fig. 2. Chemical speciation of heavy metals in soils of the study area. APA, IA, MA and SLA refer to the agricultural and pastoral area, industrial area, mining area, and salt-lake area, respectively.

mainly bound to the Fe-Mn oxide (38.7\%) and the residue (29.9\%) fraction. Most of the $\mathrm{Pb}$ also existed in the $\mathrm{Fe}-\mathrm{Mn}$ oxide fraction in the Huogeqi Copper Mine in Mongolia (Chen et al. 2018). The exchangeable $\mathrm{Pb}$ content in the soils was very low. If the oxidationreduction potential decreases, the $\mathrm{Fe}-\mathrm{Mn}$ oxide fraction may be deoxidized and $\mathrm{Pb}$ released. Therefore, $\mathrm{Pb}$ had a high potential ecological risk under reducing conditions.

Different REEs in soils showed different chemical speciation (Fig. 3). The percentage of REEs (except for Gd) in the residual fraction of the soils was in the range $50-92.1 \%$, on average, while the average percentage of the residual form of Gd reached $39.1 \%$. The organic matter fraction of REEs ranged from 4.8 to $29.8 \%$ on average, while the $\mathrm{Fe}-\mathrm{Mn}$ oxide fraction of REEs ranged from 2.0 to $19.3 \%$. The carbonate fraction of REEs ranged from 1.5 to $12.1 \%$ on average, while the average exchangeable fraction of REEs was less than $0.2 \%$. Speciation of $\mathrm{Ce}, \mathrm{Sm}, \mathrm{Gd}, \mathrm{Tb}, \mathrm{Er}, \mathrm{Tm}, \mathrm{Yb}$ and $\mathrm{Lu}$ followed the order residual $>$ organic $>\mathrm{Fe}-\mathrm{Mn}$ oxide $>$ carbonate $>$ exchangeable, while speciation of $\mathrm{Y}, \mathrm{La}, \mathrm{Pr}, \mathrm{Nd}, \mathrm{Eu}, \mathrm{Tb}$ and $\mathrm{Ho}$ followed the order residual $>$ organic $>$ carbonate $>\mathrm{Fe}-\mathrm{Mn}$ oxide $>$ exchangeable. Chemical speciation of Sc was different to that of the other REEs, following the order residual $>\mathrm{Fe}-\mathrm{Mn}$ oxide $>$ organic $>$ carbonate $>$ exchangeable. These results illustrated that REEs might show relatively low bioavailability, toxicity and potential ecological risk.

\section{Ecological risks posed by trace elements in soils of the study area}

Ecological risks posed by trace elements in soils were evaluated using the RAC method (Fig. 4). RAC values of Cd were in the range 13.02-65.92\%, showing that $\mathrm{Cd}$ poses a medium-high ecological risk in $47.1 \%$ of sampling sites. Mercury in site APA- 1 and Cd in site MA-3 represent very high ecological risks, illustrating that effective control of $\mathrm{Hg}$ and $\mathrm{Cd}$ is necessary to maintain safe ecosystems in the study area. Heavy metals including $\mathrm{Co}, \mathrm{Mo}, \mathrm{Pb}$, $\mathrm{Ni}, \mathrm{V}, \mathrm{Hg}$ and $\mathrm{Zn}$ pose a medium ecological risk in 21.0, 19.5, 19.0,
$16.1,15.3,14.0$ and $10.6 \%$ of the sampling sites, respectively. The average RAC values of REEs $\mathrm{Cu}, \mathrm{Cr}, \mathrm{Sb}$ and $\mathrm{Sn}$ ranged from 0.10 to $7.39 \%$, suggesting that these trace elements pose low ecological risks. Lead, $\mathrm{Mo}, \mathrm{Co}, \mathrm{Hg}, \mathrm{Zn}$ and $\mathrm{V}$ pose high ecological risks in $23.5,29.4,17.6,5.9,5.9$ and $5.9 \%$ of sampling sites, respectively. Heavy metals including $\mathrm{Cd}, \mathrm{Hg}, \mathrm{Pb}, \mathrm{Mo}, \mathrm{Co}, \mathrm{Zn}$ and $\mathrm{V}$ should be paid special attention to in soils of the study area due to their relatively high potential ecological risk.

\section{Source identification of trace elements in soils of the study area}

Correlation analysis was used to determine the relationship between the target trace elements of this study (Table 1). Positive correlation existed between the pairs $\mathrm{Sn}-\mathrm{Zn}, \mathrm{Sn}-\mathrm{Cd}, \mathrm{Cd}-\mathrm{Cu}, \mathrm{Cd}-\mathrm{Zn}, \mathrm{Zn}-\mathrm{Cu}$, $\mathrm{Ni}-\mathrm{Cr}, \mathrm{Ni}-\mathrm{Co}$ and $\mathrm{Co}-\mathrm{Cr}$ at a significance level of $P<0.01$. Lead showed a significant positive relationship with $\mathrm{Cu}, \mathrm{Zn}, \mathrm{Cd}$ and $\mathrm{Sn}$ at a significance level of $P<0.01$, suggesting that these heavy metals might originate from the same or similar source.

Lead isotopic ratios were effective indicators to determine the possible sources of heavy metals in the environment. Lead isotopic ratios of different functional areas of this study and previous reports have been summarized in Table 2. The average ${ }^{206} \mathrm{~Pb} /{ }^{207} \mathrm{~Pb}$ value of the agricultural and pastoral area was the highest of four areas, followed by the salt-lake area and the industrial area. The average ${ }^{206} \mathrm{~Pb} /{ }^{207} \mathrm{~Pb}$ value of the mining area was the lowest, indicating that this area had more anthropogenic $\mathrm{Pb}$. The ${ }^{206} \mathrm{~Pb} /{ }^{207} \mathrm{~Pb}$ values of all four areas were higher than those of vehicle emissions and cement. Moreover, the ${ }^{206} \mathrm{~Pb} /{ }^{207} \mathrm{~Pb}$ values of all four areas partially overlapped with those of natural sources, aerosols and coal.

The $\mathrm{Pb}$ isotopic compositions of all four areas have been plotted in Figure $5 \mathrm{a}$ and $\mathrm{b}$. A characteristic line $\left(R^{2}=0.7963\right)$ made by $\mathrm{Pb}$ isotopic ratios of all reported sources (coal, aerosol, vehicle exhaust, cement and metallurgical dust) was used to determine the possible sources of $\mathrm{Pb}$ in the soils. Overall, the ${ }^{206} \mathrm{~Pb} /{ }^{207} \mathrm{~Pb}$ and ${ }^{208} \mathrm{~Pb} /{ }^{206} \mathrm{~Pb}$ isotope ratios were similar to those of natural sources, aerosols and 
Downloaded from http://geea.lyellcollection.org/ at Cornell University Library on November 2, 2019

Speciation and source of trace elements in soils
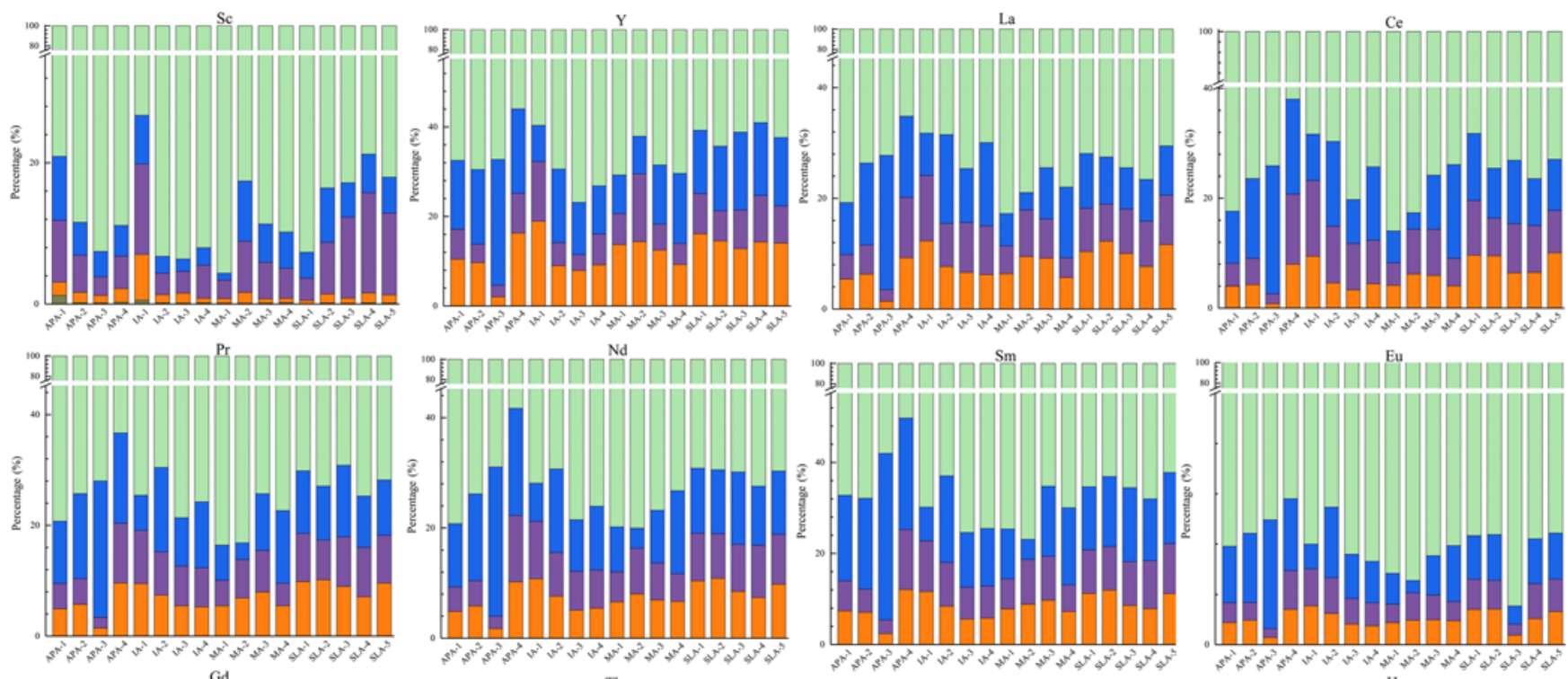

${ }^{100} \mathrm{O}=\mathrm{F}$
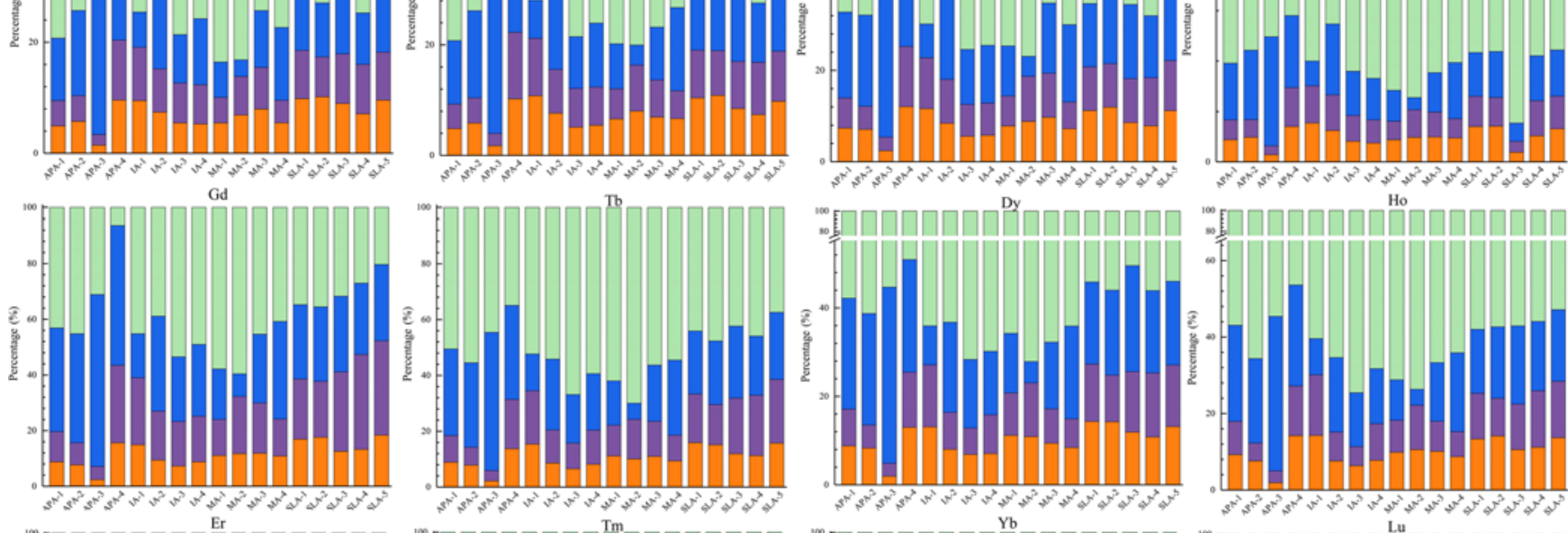

${ }^{100} \mathrm{~N}=$
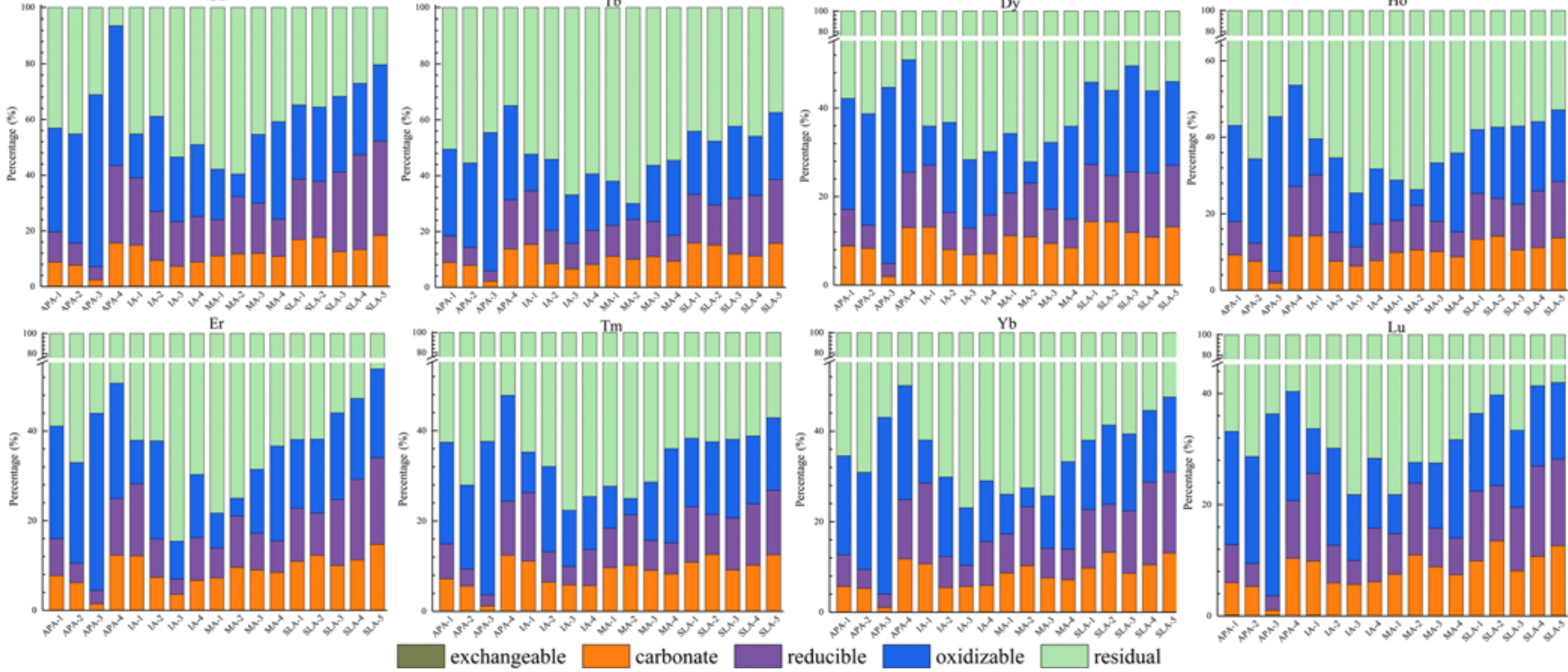

Fig. 3. Chemical speciation of rare earth elements (REEs) in soils of the study area. APA, IA, MA and SLA refer to the agricultural and pastoral area, industrial area, mining area, and salt-lake area, respectively.

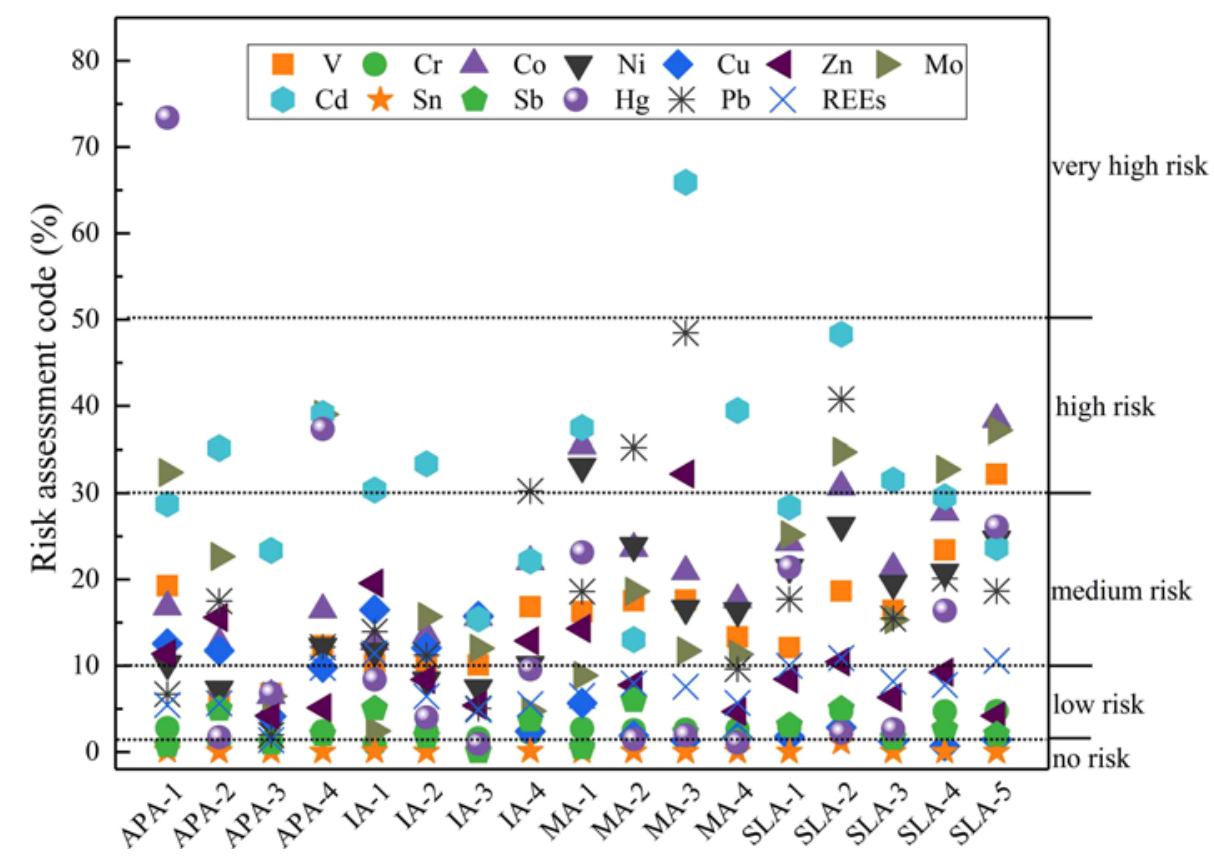

Fig. 4. Risk assessment code (RAC) of trace elements in soils of the study area. APA, IA, MA and SLA refer to the agricultural and pastoral area, industrial area, mining area, and salt-lake area, respectively. 
Downloaded from http://geea.lyellcollection.org/ at Cornell University Library on November 2, 2019

L. Li et al.

Table 1. Pearson correlation coefficients of trace elements in soil of the study area

\begin{tabular}{|c|c|c|c|c|c|c|c|c|c|c|c|c|c|}
\hline & V & $\mathrm{Cr}$ & Co & $\mathrm{Ni}$ & $\mathrm{Cu}$ & $\mathrm{Zn}$ & Mo & $\mathrm{Cd}$ & $\mathrm{Sn}$ & $\mathrm{Sb}$ & $\mathrm{Hg}$ & $\mathrm{Pb}$ & REEs \\
\hline V & 1 & & & & & & & & & & & & \\
\hline $\mathrm{Cr}$ & 0.227 & 1 & & & & & & & & & & & \\
\hline $\mathrm{Co}$ & $0.560 *$ & $\mathbf{0 . 8 4 3}^{\dagger}$ & 1 & & & & & & & & & & \\
\hline $\mathrm{Ni}$ & 0.266 & $0.9966^{\dagger}$ & $0.877^{\dagger}$ & 1 & & & & & & & & & \\
\hline $\mathrm{Cu}$ & -0.258 & -0.237 & -0.106 & -0.233 & 1 & & & & & & & & \\
\hline $\mathrm{Zn}$ & -0.173 & -0.063 & 0.044 & -0.055 & $0.645^{\dagger}$ & 1 & & & & & & & \\
\hline $\mathrm{Cd}$ & -0.178 & -0.072 & -0.064 & -0.064 & $0.660^{\dagger}$ & $0.999^{\dagger}$ & -0.093 & 1 & & & & & \\
\hline $\mathrm{Sn}$ & 0.127 & -0.238 & -0.225 & -0.225 & $0.505^{*}$ & $0.795^{\dagger}$ & -0.190 & $0.798^{\dagger}$ & 1 & & & & \\
\hline $\mathrm{Sb}$ & 0.303 & 0.058 & 0.097 & 0.097 & 0.023 & 0.226 & 0.313 & 0.228 & 0.270 & 1 & & & \\
\hline $\mathrm{Hg}$ & 0.459 & -0.137 & -0.131 & -0.131 & 0.076 & 0.301 & -0.296 & 0.299 & $0.540 *$ & 0.373 & 1 & & \\
\hline $\mathrm{Pb}$ & -0.177 & -0.065 & -0.058 & -0.058 & $0.642^{\dagger}$ & $1.000^{\dagger}$ & -0.116 & $0.999^{\dagger}$ & $0.794^{\dagger}$ & 0.219 & 0.301 & 1 & \\
\hline REEs & 0.473 & -0.370 & -0.352 & -0.352 & -0.249 & -0.235 & -0.120 & -0.232 & 0.314 & 0.368 & 0.420 & -0.237 & 1 \\
\hline
\end{tabular}

Note: $* P<0.05 ;{ }^{\dagger} P<0.01$.

coal, while they were significantly distinct from those of metallurgical dust, cement and vehicle emissions (Fig. 5a). This analysis provided the evidence that soil $\mathrm{Pb}$ from many sampling sites (except APA-1, APA-4, IA-3 and SLA-5) in the northeastern Qinghai-Tibet Plateau was from mixed sources (Fig. 5b).

The results showed that less than $53.92 \%$ of $\mathrm{Pb}$ in soils of the study area was contributed by anthropogenic activities (Fig. 5c). The anthropogenic contribution proportions for $\mathrm{Pb}$ were in the range of $0-21.52 \%$ with a mean value of $7.57 \%$ in the agricultural and pastoral area, $0-52.04 \%$ with a mean value of $23.32 \%$ in the industrial area, $4.93-53.92 \%$ with a mean value of $27.56 \%$ in the mining area, and $0-25.87 \%$ with a mean value of $13.44 \%$ for the salt-lake area. Copper, $\mathrm{Zn}, \mathrm{Cd}$ and $\mathrm{Sn}$ might have the same natural and anthropogenic contributions as $\mathrm{Pb}, \mathrm{Cu}, \mathrm{Zn}, \mathrm{Cd}$ and $\mathrm{Sn}$ might originate from the same or similar source based on the correlation analysis. Moreover, anthropogenic contributions in the industrial and mining area were higher in comparison with the other areas. Anthropogenic $\mathrm{Pb}$ contribution was low in the agricultural and pastoral area, as well as the salt-lake area, with relatively less anthropogenic disturbance.

\section{Importance and application of this study}

Total concentrations of trace elements in soils have been widely used to evaluate pollution and potential ecological risks (Wu et al. 2016, 2018a; L. Li et al. 2018). However, information to determine the critical element with stronger mobility and bioavailability cannot be obtained through the use of total concentration data alone. Thus, speciation analysis provides useful information on different fractions of these elements hosted in soils or other materials. Moreover, studies on speciation and ecological risk of trace elements including REEs in soils of the Qinghai-Tibet Plateau and other high-elevation areas are limited. Therefore, this study will provide the theoretical basis for soil quality management in the high-elevation areas.

Trace elements generally include heavy metals, REEs, and some other elements such as radium and barium. However, many studies have paid more attention to the distribution of heavy metals in the environments since heavy metals have harmful effects on ecosystems and humans (Tan et al. 2006; Lin et al. 2014; Wu et al. 2018a). This study provides comprehensive information on the distribution, speciation, risks and possible sources of heavy metals and REEs in soils of the Qinghai-Tibet Plateau, and provides thorough insight into the soil quality with respect to trace elements.

Source apportionment is important for pollution control and prevention (Wu et al. 2016, 2018a). Isotope-based source apportionment generally provides more direct evidence for determining the contribution proportions of different sources. However, this method has not been widely used to identify the possible sources of trace elements in the Qinghai-Tibet Plateau. Therefore, this study discussed the contribution proportions of natural and anthropogenic lead sources, and addressed new information on the source apportionment of trace elements in soils of the high-elevation areas. Trace element isotopes of some trace elements such as $\mathrm{Hg}, \mathrm{Sr}, \mathrm{Cd}, \mathrm{Cr}, \mathrm{Cu}$ and $\mathrm{Zn}$ can also be used for source identification and apportionment (J.-Z. Feng et al. 2010; X. Feng et al. 2010; Sun et al. 2017). It will be more accurate to determine different pollution sources and contribution proportions by using multiple isotopes in the future.

The Qinghai-Tibet Plateau is a unique geological feature in the world which attracts global attention. This study, focused on trace

Table 2. Pb isotopic compositions from four areas, natural sources and pollution sources

\begin{tabular}{llll}
\hline Sample & ${ }^{206} \mathrm{~Pb} /{ }^{207} \mathrm{~Pb}$ & ${ }^{208} \mathrm{~Pb} /{ }^{206} \mathrm{~Pb}$ & Reference \\
\hline Agricultural and pastoral area & $1.187-1.208$ & $2.054-2.078$ & This study \\
Industrial area & $1.167-1.224$ & $2.031-2.099$ & This study \\
Mining area & $1.166-1.197$ & $2.059-2.122$ & This study \\
Salt-lake area & $1.184-1.201$ & $2.065-2.089$ & This study \\
Natural source & $1.183-1.200$ & $2.077-2.096$ & Zhu (1995), Zhu et al. (1998, 2001), Millot et al. (2004) and Lee et al. (2007) \\
Coal & $1.140-1.192$ & $2.057-2.117$ & Mukai et al. (1993), Mukai et al. (2001) and Tan et al. (2006) \\
Vehicle exhaust (leaded and unleaded) & $1.110-1.147$ & $2.123-2.193$ & Chen et al. (2005) \\
Cement & 1.163 & 2.104 & Tan et al. (2006) \\
Metallurgical dust & 1.172 & 2.078 & Tan et al. (2006) \\
Aerosol & $1.131-1.189$ & $2.100-2.133$ & Bollhöfer \& Rosman (2001), Mukai et al. (2001), Chen et al. (2005), Hsu et al. (2006), \\
& & & Lee et al. (2007), Liu et al. (2014) and Zhu et al. (2010) \\
\hline
\end{tabular}


Speciation and source of trace elements in soils
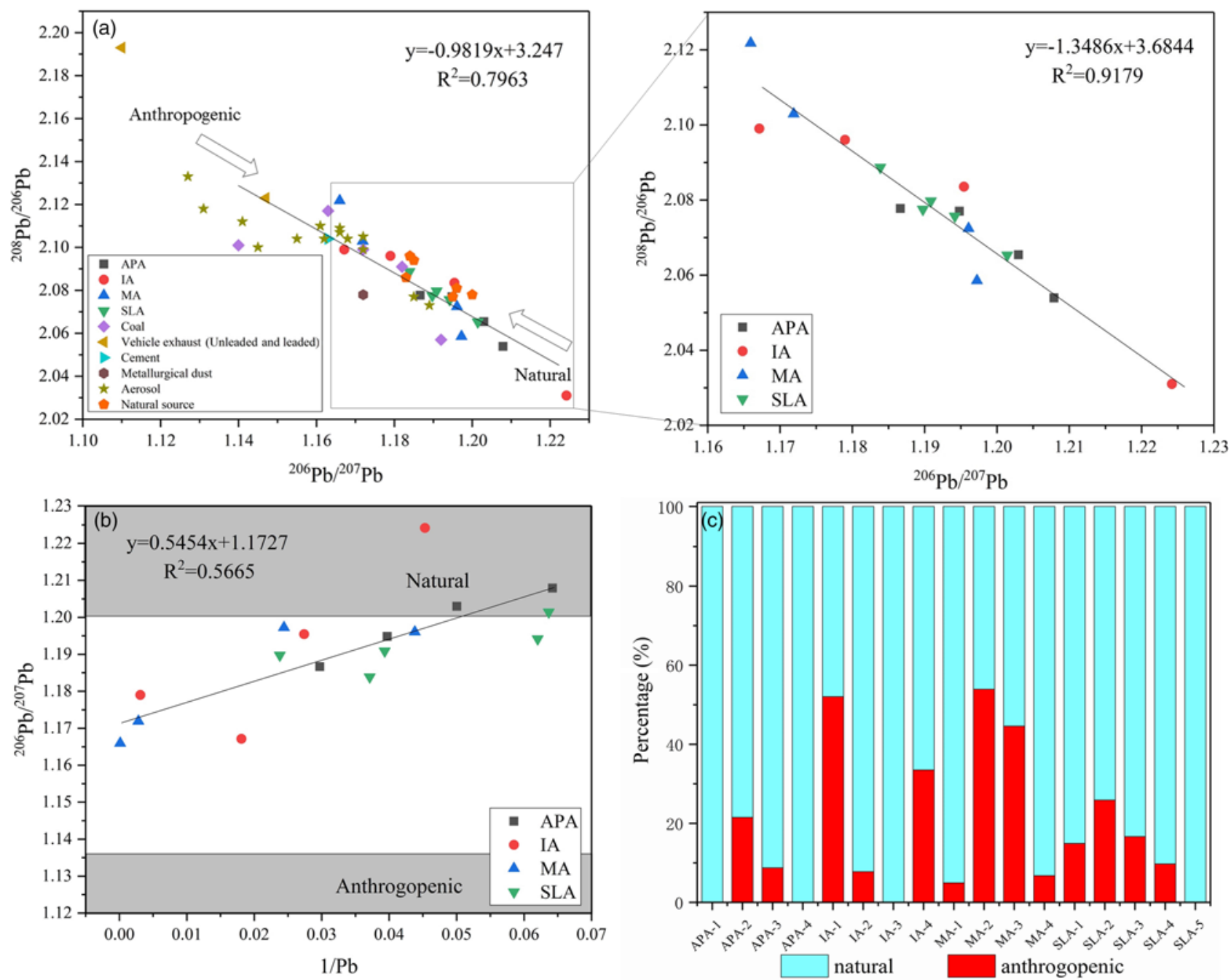

Fig. 5. (a) Correlation between ${ }^{208} \mathrm{~Pb} /{ }^{206} \mathrm{~Pb}$ and ${ }^{206} \mathrm{~Pb} /{ }^{207} \mathrm{~Pb}$ of the samples (this work) and reference source samples. (b) Correlation between ${ }^{206} \mathrm{~Pb} /{ }^{207} \mathrm{~Pb}$ and $1 / \mathrm{Pb}$ in soil samples of this study. (c) $\mathrm{Pb}$ isotopic compositions in soil samples of this study. APA, IA, MA and SLA refer to the agricultural and pastoral area, industrial area, mining area, and salt-lake area, respectively.

elements in the soils of this region, will provide some useful information on soil pollution control and environmental management in similar high-elevation areas of the world.

\section{Conclusions}

The distribution of heavy metals in soils of the study area showed a significant spatial variation. The average concentrations of $\mathrm{Cd}, \mathrm{Pb}$, $\mathrm{Hg}, \mathrm{Cr}$ and $\mathrm{Zn}$ were over 6 times their corresponding background values. The highest concentration of $\mathrm{Cr}$ and $\mathrm{Hg}$ occurred in soils of the eastern and western study area, respectively. The maximal concentration of $\mathrm{Pb}, \mathrm{Zn}$ and $\mathrm{Cd}$ occurred in soils of the middle study area. REEs in soils were mostly derived from natural origins with an average content of $178 \mathrm{mg} \mathrm{kg}^{-1}$. The residual fraction was the dominant form of $\mathrm{V}, \mathrm{Cr}, \mathrm{Cu}, \mathrm{Sn}, \mathrm{Sb}, \mathrm{Hg}$ and REEs. RAC analysis showed that $\mathrm{Cd}$ should be recognized as a priority pollutant in the study area. Correlation analysis indicated that $\mathrm{Pb}, \mathrm{Cu}, \mathrm{Zn}, \mathrm{Cd}$ and $\mathrm{Sn}$ might originate from the same or similar source. The lead isotopic compositions exhibited by $\mathrm{Pb}$ in the soils were influenced by a mixed contribution of natural and anthropogenic sources. The anthropogenic $\mathrm{Pb}$ contribution proportion was in the range $0-53.92 \%$. The average percentages of anthropogenic $\mathrm{Pb}$ in the four types of areas showed a positive correlation with the intensity of anthropogenic activities.

Heavy metals including $\mathrm{Pb}, \mathrm{Zn}$ and $\mathrm{Cd}$ should be paid more attention, in line with the speciation and source identification results. Effective management of the anthropogenic activities in the northeastern Qinghai-Tibet Plateau is needed to control the heavy metal pollution in this area.

Acknowledgements The authors would like to thank the reviewers for their valuable comments and suggestions on the manuscript.

Funding This work was financially supported by the National Natural Science Foundation of China (grant No. 41671319), the One Hundred Talents Programme of the Chinese Academy of Sciences (grant Nos Y610061033 and Y629041021), the Taishan Scholar Programme of Shandong Province (grant No. tsqn201812116), the Thousand Talents Plan of Qinghai Province (grant No. Y740171071), the Natural Science Foundation of Qinghai Province (grant No. 2019-ZJ-909) and the Two-Hundred Talents Plan of Yantai (grant No. Y739011021).

Author contributions LL: Data curation (Lead), Formal analysis (Lead), Writing - Original Draft (Equal); JW: Conceptualization (Lead), Funding acquisition (Equal), Investigation (Lead), Project administration (Lead), Supervision (Lead), Writing - Original Draft (Equal), Writing - Review \& Editing (Lead); JL: Conceptualization (Equal), Funding acquisition (Equal), Investigation (Equal), Project administration (Equal), Supervision (Equal), Writing - Review \& Editing (Equal); JX: Data curation (Supporting), Formal analysis (Equal).

\section{References}

Bollhöfer, A. \& Rosman, K.J. 2001. Isotopic source signatures for atmospheric lead: The Northern Hemisphere. Geochimica et Cosmochimica Acta, 65 1727-1740, https://doi.org/10.1016/S0016-7037(00)00630-X 
Chen, J., Tan, M. et al. 2005. A lead isotope record of Shanghai atmospheric lead emissions in total suspended particles during the period of phasing out of leaded gasoline. Atmospheric Environment, 39, 1245-1253, https://doi.org/ 10.1016/j.atmosenv.2004.10.041

Chen, L., Wu, J. et al. 2018. Speciation, fate and transport, and ecological risks of $\mathrm{Cu}, \mathrm{Pb}$, and $\mathrm{Zn}$ in tailings from Huogeqi Copper Mine, Inner Mongolia, China. Journal of Chemistry, 2018, Article ID 2340542, https://oi.org/10.1155/ 2018/2340542

Cheng, H. \& Hu, Y. 2010. Lead $(\mathrm{Pb})$ isotopic fingerprinting and its applications in lead pollution studies in China: A review. Environmental Pollution, 158, 1134-1146, https://doi.org/10.1016/j.envpol.2009.12.028

Cong, Z., Kang, S., Luo, C., Li, Q., Huang, J., Gao, S. \& Li, X. 2011. Trace elements and lead isotopic composition of $\mathrm{PM}_{10}$ in Lhasa, Tibet. Atmospheric Environment, 45, 6210-6215, https://doi.org/10.1016/j.atmosenv.2011.07.060

Dai, L., Wang, L. et al. 2019. Geostatistical analyses and co-occurrence correlations of heavy metals distribution with various types of land use within a watershed in eastern QingHai-Tibet Plateau, China. Science of the Total Environment, 653, 849-859, https://doi.org/10.1016/j.scitotenv.2018.10.386

Dessai, D.V.G. \& Nayak, G.N. 2009. Distribution and speciation of selected metals in surface sediments, from the tropical Zuari estuary, central west coast of India. Environmental Monitoring and Assessment, 158, 117-137, https:// doi.org/10.1007/s10661-008-0575-0

Feng, J.-Z., Hu, Z.-G., Cui, J.-Y. \& Zhu, L.-P. 2010. Distributions of lead isotopes with grain size in aeolian deposits. Terra Nova, 22, 257-263, https://doi.org/ 10.1111/j.1365-3121.2010.00941.X

Feng, X., Foucher, D., Hintelmann, H., Yan, H., He, T. \& Qiu, G. 2010. Tracing mercury contamination sources in sediments using mercury isotope compositions. Environmental Science \& Technology, 44, 3363-3368, https://doi.org/ 10.1021/es9039488

Fernandes, M.C. \& Nayak, G.N. 2015. Speciation of metals and their distribution in tropical estuarine mudflat sediments, southwest coast of India. Ecotoxicology and Environmental Safety, 122, 68-75, https://doi.org/10.1016/j.ecoenv.2015.07.016

Fernandes, M.C., Nayak, G.N., Pande, A., Volvoikar, S.P. \& Dessai, D.R.G. 2014. Depositional environment of mudflats and mangroves and bioavailability of selected metals within mudflats in a tropical estuary. Environmental Earth Sciences, 72, 1861-1875, https://doi.org/10.1007/s12665-014-3095-y

Guo, G., Yuan, T., Wang, W., Li, D., Cheng, J., Gao, Y. \& Zhou, P. 2011. Bioavailability, mobility, and toxicity of $\mathrm{Cu}$ in soils around the Dexing $\mathrm{Cu}$ mine in China. Environmental Geochemistry and Health, 33, 217-224, https:// doi.org/10.1007/s10653-010-9334-6

Han, W., Gao, G., Geng, J., Li, Y. \& Wang, Y. 2018. Ecological and health risks assessment and spatial distribution of residual heavy metals in the soil of an ewaste circular economy park in Tianjin, China. Chemosphere, 197, 325-335, https://doi.org/10.1016/j.chemosphere.2018.01.043

Hsu, S.-C., Liu, S.C., Jeng, W.-L., Chou, C.C.K., Hsu, R.-T., Huang, Y.-T. \& Chen, Y.-W. 2006. Lead isotope ratios in ambient aerosols from Taipei, Taiwan: Identifying long-range transport of airborne $\mathrm{Pb}$ from the Yangtze Delta. Atmospheric Environment, 40, 5393-5404, https://doi.org/10.1016/j. atmosenv.2006.05.003

Ke, X., Gui, S., Huang, H., Zhang, H., Wang, C. \& Guo, W. 2017. Ecological risk assessment and source identification for heavy metals in surface sediment from the Liaohe River protected area, China. Chemosphere, 175, 473-481, https://doi.org/10.1016/j.chemosphere.2017.02.029

Kong, J., Guo, Q. et al. 2018. Contamination of heavy metals and isotopic tracing of $\mathrm{Pb}$ in surface and profile soils in a polluted farmland from a typical karst area in southern China. Science of the Total Environment, 637-638, 1035-1045, https://doi.org/10.1016/j.scitotenv.2018.05.034

Lee, C.S.L., Li, X.D., Zhang, G., Li, J., Ding, A.-J. \& Wang, T. 2007. Heavy metals and $\mathrm{Pb}$ isotopic composition of aerosols in urban and suburban areas of Hong Kong and Guangzhou, South China - Evidence of the long-range transport of air contaminants. Atmospheric Environment, 41, 432-447, https:// doi.org/10.1016/j.atmosenv.2006.07.035

Lee, K., Hur, S.D. et al. 2011. Isotopic signatures for natural versus anthropogenic $\mathrm{Pb}$ in high-altitude Mt. Everest ice cores during the past 800 years. Science of the Total Environment, 412-413, 194-202, https://doi.org/ 10.1016/j.scitotenv.2011.10.002

Li, G., Han, L., Peng, W., Gao, B., Xu, D. \& Wan, X. 2018. Identification of anthropogenic inputs of trace metals in lake sediments using geochemical baseline and $\mathrm{Pb}$ isotopic composition. Ecotoxicology and Environmental Safety, 164, 226-233, https://doi.org/10.1016/j.ecoenv.2018.08.014

Li, H. \& Ji, H. 2017. Chemical speciation, vertical profile and human health risk assessment of heavy metals in soils from coal-mine brownfield, Beijing, China. Journal of Geochemical Exploration, 183, 22-32, https://doi.org/10. 1016/j.gexplo.2017.09.012

Li, L., Wu, J., Lu, J., Min, X., Xu, J. \& Yang, L. 2018. Distribution, pollution, bioaccumulation, and ecological risks of trace elements in soils of the northeastern Qinghai-Tibet Plateau. Ecotoxicology and Environmental Safety, 166, 345-353, https://doi.org/10.1016/j.ecoenv.2018.09.110

Liang, G., Zhang, B. et al. 2017. Evaluation of heavy metal mobilization in creek sediment: Influence of RAC values and ambient environmental factors. Science of the Total Environment, 607-608, 1339-1347, https://doi.org/10. 1016/j.scitotenv.2017.06.238
Lin, C., Liu, Y., Li, W. \& Ji, W. 2014. Speciation, distribution, and potential ecological risk assessment of heavy metals in Xiamen Bay surface sediment. Acta Oceanologica Sinica, 33, 13-21, https://doi.org/10.1007/s13131-0140453-2

Liu, Q., Liu, Y., Yin, J., Zhang, M. \& Zhang, T. 2014. Chemical characteristics and source apportionment of $\mathrm{PM}_{10}$ during Asian dust storm and non-dust storm days in Beijing. Atmospheric Environment, 91, 85-94, https://doi.org/ 10.1016/j.atmosenv.2014.03.057

Meng, J., Tao, M., Wang, L., Liu, X. \& Xu, J. 2018. Changes in heavy metal bioavailability and speciation from a $\mathrm{Pb}-\mathrm{Zn}$ mining soil amended with biochars from co-pyrolysis of rice straw and swine manure. Science of the Total Environment, 633, 300-307, https://doi.org/10.1016/j.scitotenv.2018.03.199

Millot, R., Allègre, C.-J., Gaillardet, J. \& Roy, S. 2004. Lead isotopic systematics of major river sediments: a new estimate of the $\mathrm{Pb}$ isotopic composition of the Upper Continental Crust. Chemical Geology, 203, 75-90, https://doi.org/10. 1016/j.chemgeo.2003.09.002

Mukai, H., Furuta, N., Fujii, T., Ambe, Y., Sakamoto, K. \& Hashimoto, Y. 1993. Characterization of sources of lead in the urban air of Asia using ratios of stable lead isotopes. Environmental Science \& Technology, 27, 1347-1356, https:// doi.org/10.1021/es00044a009

Mukai, H., Tanaka, A. et al. 2001. Regional Characteristics of Sulfur and Lead Isotope Ratios in the Atmosphere at Several Chinese Urban Sites. Environmental Science \& Technology, 35, 1064-1071, https://doi.org/10.1021/es001399u

Seshan, B.R.R., Natesan, U. \& Deepthi, K. 2010. Geochemical and statistical approach for evaluation of heavy metal pollution in core sediments in southeast coast of India. International Journal of Environmental Science and Technology, 7, 291-306, https://doi.org/10.1007/BF03326139

Sun, J., Hu, G., Yu, R., Lin, C., Wang, X. \& Huang, Y. 2017. Human health risk assessment and source analysis of metals in soils along the G324 Roadside, China, by $\mathrm{Pb}$ and $\mathrm{Sr}$ isotopic tracing. Geoderma, 305, 293-304, https://doi. org/10.1016/j.geoderma.2017.06.017

Tan, M., Zhang, G. et al. 2006. Comprehensive study of lead pollution in Shanghai by multiple techniques. Analytical Chemistry, 78, 8044-8050, https://doi.org/10.1021/ac061365q

Tessier, A., Cambell, P.G.C. \& Bisson, M. 1979. Sequential extraction procedure for the speciation of particulate trace metals. Analytical Chemistry, 51, 844-851, https://doi.org/10.1021/ac50043a017

Wu, J., Duan, D., Lu, J., Luo, Y., Wen, X., Guo, X. \& Boman, B.J. 2016. Inorganic pollution around the Qinghai-Tibet Plateau: An overview of the current observations. Science of the Total Environment, 550, 628-636, https:// doi.org/10.1016/j.scitotenv.2016.01.136

Wu, J., Lu, J., Li, L., Min, X. \& Luo, Y. 2018 a. Pollution, ecological-health risks, and sources of heavy metals in soil of the northeastern Qinghai-Tibet Plateau. Chemosphere, 201, 234-242, https://doi.org/10.1016/j.chemosphere.2018.02. 122

Wu, J., Lu, J., Li, L., Min, X., Zhang, Z. \& Luo, Y. 2018b. Distribution, pollution, and ecological risks of rare earth elements in soil of the northeastern QinghaiTibet Plateau. Human and Ecological Risk Assessment: An International Journal, https://doi.org/10.1080/10807039.2018.1475215

$\mathrm{Yu}, \mathrm{G} ., \mathrm{Xu}$, J. et al. 2013. Lead isotopic composition of insoluble particles from widespread mountain glaciers in western china: Natural vs. anthropogenic sources. Atmospheric Environment, 75, 224-232, https://doi.org/10.1016/j. atmosenv.2013.04.018

Zhang, G., Yang, F., Zhao, W., Zhao, Y., Yang, J. \& Gong, Z. 2007. Historical change of soil $\mathrm{Pb}$ content and $\mathrm{Pb}$ isotope signatures of the cultural layers in urban Nanjing. Catena, 69, 51-56, https://doi.org/10.1016/j.catena.2006.04.013

Zhang, R., Zhang, F., Guan, M., Shu, Y. \& Li, T. 2017. Sources and chronology of combustion-derived pollution to Shilianghe Reservoir, eastern China: Evidences from PAHs profiles, $\mathrm{As}, \mathrm{Hg}, \mathrm{Pb}$ and $\mathrm{Pb}$ isotopes. Catena, 149, 232-240, https://doi.org/10.1016/j.catena.2016.09.020

Zhang, Z., Zheng, D., Xue, Z., Wu, H. \& Jiang, M. 2019. Identification of anthropogenic contributions to heavy metals in wetland soils of the Karuola Glacier in the Qinghai-Tibetan Plateau. Ecological Indicators, 98, 678-685, https://doi.org/10.1016/j.ecolind.2018.11.052

Zhu, B. 1995. The mapping of geochemical provinces in China based on $\mathrm{Pb}$ isotopes. Journal of Geochemical Exploration, 55, 171-181, https://doi.org/ 10.1016/0375-6742(95)00011-9

Zhu, B., Chang, X., Qiu, H. \& Sun, D. 1998. Characteristics of Proterozoic basements on the geochemical steep zones in the continent of China and their implications for setting of super large deposits. Science in China Series D, 41, (Suppl.), 54-64.

Zhu, B.-Q., Chen, Y.-W. \& Peng, J.-H. 2001. Lead isotope geochemistry of the urban environment in the Pearl River Delta. Applied Geochemistry, 16, 409-417, https://doi.org/10.1016/S0883-2927(00)00047-0

Zhu, H., Yuan, X. et al. 2012. Ecological risk assessment of heavy metals in sediments of Xiawan Port based on modified potential ecological risk index. Transactions of Nonferrous Metals Society of China, 22, 1470-1477, https:// doi.org/10.1016/S1003-6326(11)61343-5

Zhu, L., Guo, L., Gao, Z., Yin, G., Lee, B., Wang, F. \& Xu, J. 2010. Source and distribution of lead in the surface sediments from the South China Sea as derived from Pb isotopes. Marine Pollution Bulletin, 60, 2144-2153, https:/ doi.org/10.1016/j.marpolbul.2010.07.026 